\title{
Glaciomarine sedimentation and the relations between the acoustic impedance and grain size in Bransfield Basin, Antartctica
}

\author{
Julia Machado, Mateus Martins, Ana Carla Pinheiro, Fabrício Ferreira, Arthur Ayres, Rosemary Vieira
}

Copyright 2019, SBGf - Sociedade Brasileira de Geofísica

This paper was prepared for presentation during the $16^{\text {th }}$ International Congress of the Brazilian Geophysical Society held in Rio de Janeiro, Brazil, 19-22 August 2019.

Contents of this paper were reviewed by the Technical Committee of the $16^{\text {th }}$ International Congress of the Brazilian Geophysical Society and do not necessarily represent any position of the SBGf, its officers or members. Electronic reproduction or storage of any part of this paper for commercial purposes without the written consent of the Brazilian Geophysical Society is prohibited.

\section{Abstract}

This work aims to describe the glaciomarine sedimentation of the Bransfield Basin and to analyze the behavior of the acoustic impedance in relation to granulometric data to understand how they are related. For this purpose, data from six cores from the Antarctic expeditions OPERANTAR XXXIV and XXXV were carried out aboard the Polar Admiral Maximiano Ship. The samples were from 150 to $1400 \mathrm{~cm}$ in length and were collected in the Bransfield Basin located in the South Shetland Islands archipelago. The methodology consisted of logging of the cores in Laboratory of Sedimentary and Environmental Processes (LAPSA) of the Institute of Geosciences of Fluminense Federal University using Multi-sensor Core Logger (MSCL-S) of Geotek® Ltd. for acoustic impedance measurements. In the proximal part, the results indicate impedance values varying from $2151.98 \mathrm{~g} / \mathrm{cm}^{3} \cdot \mathrm{m} / \mathrm{s}$ to $3358.11 \mathrm{~g} / \mathrm{cm}^{3} \cdot \mathrm{m} / \mathrm{s}$ with average of $2466.33 \mathrm{~g} / \mathrm{cm}^{3} \cdot \mathrm{m} / \mathrm{s}$ and a standard deviation of 310.34 $\mathrm{g} / \mathrm{cm}^{3} \cdot \mathrm{m} / \mathrm{s}$. The sand content varied between $0 \%$ and $77.30 \%$, with a mean of $12.55 \%$ and standard deviation of $21.37 \%$ The values of clay content ranged from $0 \%$ to $85.57 \%$, with a mean of $73.32 \%$ and a standard deviation of $20.55 \%$ Regarding the correlations, in the proximal part, a correlation was found between the acoustic impedance and the mean grain size $(\mathrm{PHI})$ of $\mathrm{R}^{2}=0.87$. $\mathrm{R}^{2}=0.94$ between impedance and sand and also silt. Between impedance and clay, $\mathrm{R}^{2}=0.82$. In the most distal portion from the Islands, acoustic impedance ranged from $1699.71 \mathrm{~g} / \mathrm{cm}^{3} \cdot \mathrm{m} / \mathrm{s}$ to $2580.83 \mathrm{~g} / \mathrm{cm}^{3} \cdot \mathrm{m} / \mathrm{s}$, with a average of $2125.63 \mathrm{~g} / \mathrm{cm}^{3} \cdot \mathrm{m} / \mathrm{s}$ and standard deviation of $169,81 \mathrm{~g} /$ $\mathrm{cm}^{3} . \mathrm{m} / \mathrm{s}$ In relation to $\mathrm{PHI}$, the results indicate values between $3.11 \%$ and $8.20 \%$ with a mean of $6.58 \%$ and a standard deviation of $0.47 \%$. Sand varied between $0 \%$ and $35.17 \%$ with a average of $6.18 \%$ and a standard deviation of $5.29 \%$. Silt between $0 \%$ and $89.30 \%$, and average of $79.14 \%$ and a standard deviation of $13.23 \%$. Clay had a variation from $0 \%$ to $28.98 \%$, an average of $12.25 \%$ and a standard deviation of $3.13 \%$. In the distal part, we obtained weak correlations among all observed parameters.

\section{Introduction}

Approximately $98 \%$ of the Antarctic extent is covered by ice (INGOLFSSON et al., 1998). How polar areas have greater environmental sensitivity to climate change, the study of the region's sedimentary evolution is important to understanding the consequences of climate change related environmental changes.

The acoustic impedance has been studied in several environments because it provides information about the $P$ wave velocity, density and consequently the type of sediment studied (Ayres, 1998). In addition, the PHI scale provides important information about the mean grain size. As sample are punctual and have several problems in the acquisition step, it would be convenient to extract sizing information from acoustic data.

Although there are studies correlating physical parameters with particle size analysis in different environments, no work correlates these parameters in glacial environment analyzing proximal and distal regions.

Therefore, the objective of this work is to describe the glaciomarine sedimentation of the Bransfield Basin in distal and proximal environments (Figure 1) and to analyze the behavior of the acoustic impedance with the granulometric data to understand how they are related.

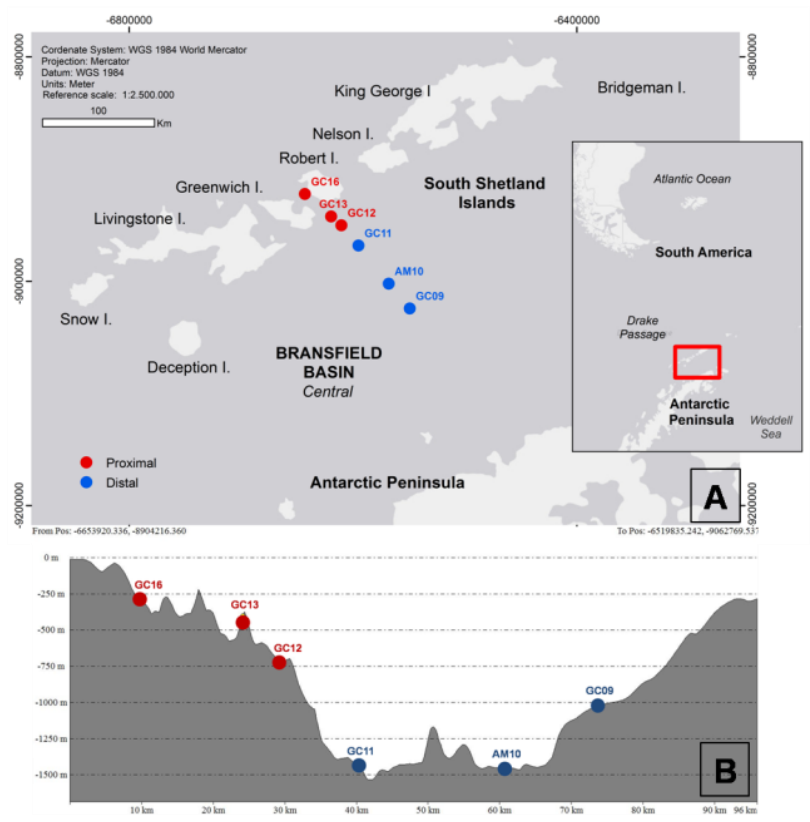

Figure 1 - A. Study area map; B. Bathymetry of Bransfield Bay. 


\section{Method}

The research was conducted in three main stages:

1. Acquisition of 6 cores from the OPERANTAR XXXIV and XXXV expeditions carried on board the Polar Admiral Maximiano Ship, of the Brazilian Navy. These samples were collected on a transect from the South Shetland Islands (ISS) towards the Antarctic Peninsula (PA). Their sizes vary from 150 to 520 centimeters and were collected through the Gravity Corer sampler at depths ranging from 300 to 1400 meters;

2. The second stage consisted of the logging using the Multi-sensor Core Logger (MSCL-S) Geotek ${ }^{\circledR}$ Ltd. in the Laboratory of Sedimentary and Environmental Processes (LAPSA) of the Institute of Geosciences of Fluminense Federal University for measurements of physical properties. The properties used in this work is acoustic impedance;

3. Granulometric analysis of the samples by diffraction particle analyzer using the Mastersizer 2000 laser granulometer (Malvern Instruments):

4. Processing and statistical interpretation of results using $\mathrm{R}^{2}$ correlation coefficient and analysis of their relations with sedimentary processes.

\section{Results}

Closest to South Shetland Islands, the results indicate acoustic impedance values varying from 2151.98 $\mathrm{g} / \mathrm{cm}^{3} . \mathrm{m} / \mathrm{s}$ to $3358.11 \mathrm{~g} / \mathrm{cm}^{3} . \mathrm{m} / \mathrm{s}$. For PHI, values between 2.31 and 10.84 were found. Sand varied between $0 \%$ and $77.30 \%$, silt between $0 \%$ and $87.57 \%$ and clay had a variation from $0 \%$ to $25.28 \%$.

In the most distal portion from the Islands, acoustic impedance results ranged from $1699.71 \mathrm{~g} / \mathrm{cm}^{3} . \mathrm{m} / \mathrm{s}$ to $2580.83 \mathrm{~g} / \mathrm{cm}^{3} . \mathrm{m} / \mathrm{s}$. In relation to $\mathrm{PHI}$, the results indicate values between 3.11 and 8.20 . Sand varied between 0 and $35.17 \%$, silt between $0 \%$ and $89.30 \%$ and clay had a variation from $0 \%$ to $28.98 \%$ (Table 1 ).

Table 1 - Statistical summary of mean impedance values, mean grain size (PHI), sand, silt and clay content.

\begin{tabular}{cccccc} 
& \multicolumn{5}{c}{ PROXIMAL } \\
\cline { 2 - 6 } & $\begin{array}{c}\text { Acoustic } \\
\text { Impedance } \\
\left(\mathrm{g} / \mathrm{cm}^{3} \cdot \mathrm{m} / \mathrm{s}\right)\end{array}$ & $\begin{array}{c}\text { Mean } \\
\text { Grain Size } \\
(\Phi)\end{array}$ & $\begin{array}{c}\text { Sand } \\
(\%)\end{array}$ & $\begin{array}{c}\text { Silt } \\
(\%)\end{array}$ & $\begin{array}{c}\text { Clay } \\
(\%)\end{array}$ \\
\hline \hline Minimum & 2151,98 & 2,31 & 0,00 & 0,00 & 0,00 \\
Maximum & 3358,11 & 10,84 & 77,30 & 87,57 & 25,28 \\
Average & 2466,33 & 6,29 & 12,55 & 73,32 & 12,32 \\
Stardard Deviation & 310,34 & 1,42 & 21,37 & 20,55 & 4,54 \\
\hline & \multicolumn{5}{c}{ DISTAL } \\
\cline { 2 - 6 } & Acoustic & Mean & Sand & Silt & Clay \\
& Impedance & Grain Size & $(\%)$ & $(\%)$ & $(\%)$ \\
\hline \hline Minimum & $\left(\mathrm{g} / \mathrm{cm}^{3} \cdot \mathrm{m} / \mathrm{s}\right)$ & $(\Phi)$ & & & \\
Maximum & 1699,71 & 3,11 & 0,00 & 0,00 & 0,00 \\
Average & 2580,83 & 8,20 & 35,17 & 89,30 & 28,98 \\
Stardard Deviation & 2125,63 & 6,58 & 6,18 & 79,14 & 12,25 \\
\hline \hline
\end{tabular}

It is observed that in all the study area there is a predominance of silt. However, the proximal region has a higher sand content in relation to the distal (Figure 2).

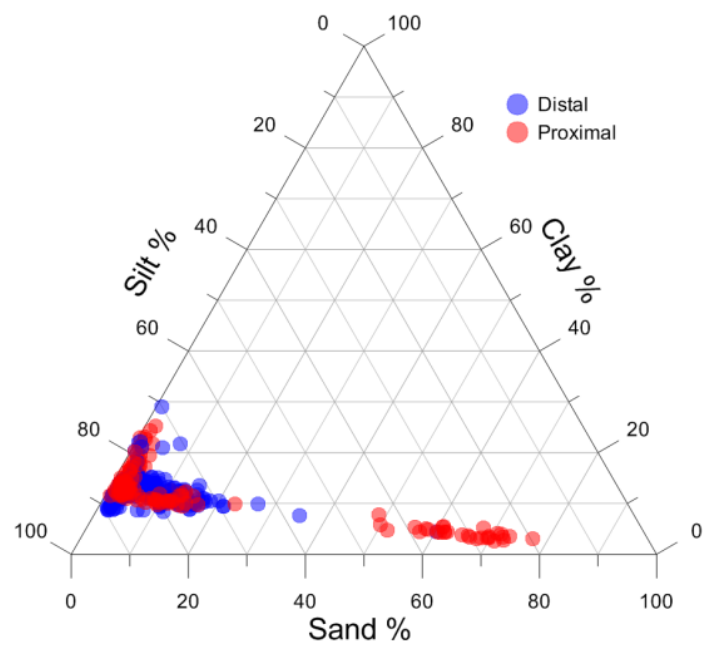

Figure 2 - Ternary diagram of the sand, silt and clay contents of the proximal and distal portions.

Correlation graphs were plotted between the impedance and the grain sizes, which demonstrated good correlation in the region closest to the South Shetland Islands. The acoustic impedance and $\mathrm{PHI}$ had a correlation index $\mathrm{R}^{2}=0.8$ (Figure $3 \mathrm{~A}$ ). The impedance obtained correlation $\mathrm{R}^{2}=0.94$ (Figure 3B) with sand also with silt (Figure 3C). With clay, the correlation with impedance was $R^{2}=0.82$ (Figure 3D).

The distal part presented weak or no correlation between the parameters. The acoustic impedance and $\mathrm{PHI}$, $\mathrm{R}^{2}=0.08$ (Figure 3A). The impedance obtained correlation $\mathrm{R}^{2}=0.05$ with sand (Figure $3 B$ ),$R^{2}=0.21$ with silt (Figure 3C) and $R^{2}=0.37$ with clay (Figure 3D).
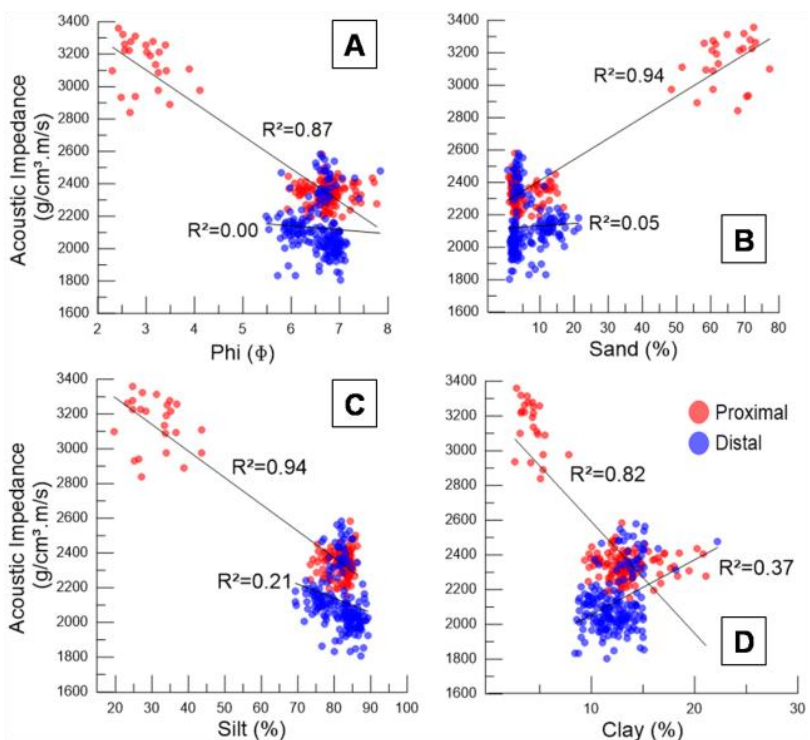

Figure 3-Correlation graphs of proximal (red) and distal (blue) regions. A. Acoustic impedance and PHI; $B$. 
Acoustic impedance and sand; C. Acoustic impedance and slte; D. Acoustic impedance and clay.

\section{Conclusions}

The results obtained in this work show that there is a good relation between the impedance, $\mathrm{PHI}$ and sand, silt and clay contents in Antarctic marine sediments in the region proximal to the South Shetland Islands. The sand content is higher in this area than in the distal portion and forms a predominantly silt-sandy sedimentation as demonstrated by Fabrés et. al (2002) and Garcia et. al. (2008). It is observed a clear trend of increase of the impedance with the increase of the sand content. These factors demonstrate that the proximal region is more influenced by the sedimentary processes typical of the continental environment.

In the region distal to the Islands, there is a weak correlation between the analyzed parameters and the predominance of silt-clayey sediments, showing that sedimentation is more influenced by marine processes.

\section{Acknowledgments}

Laboratory of Sedimentary and Environmental Processes (LAPSA) of the Institute of Geosciences of Fluminense Federal University

\section{References}

AYRES NETO, A. 1998. Relationships Between Physical Properties and Sedimentological Parameters of Near Surface Marine Sediments and their Applicability in the Solution of Engineering and Environmental Problems. University of Kiel, Germany.

AYRES NETO, A. et al. Geotechnical Influence on the Acoustic Properties of Marine Sediments of the Santos Basin, Brazil, Marine Georesources \& Geotechnology, 31:2, 125-136, 2013.

FABRÉS, J. et al. Bransfield Basin fine grained sediments: Late Holocene sedimentary processes and oceanographic conditions. The Holocene, v. 10, p. 153182, 2002.

GARCíA, M. et al. New insights on the post-rift seismic stratigraphic architecture and sedimentary evolution of the Antarctic Peninsula margin (Central Bransfield Basin). Marine Geology, v. 251, n. 3-4, p. 167-182, 2008.

INGÓLFSSON, O. et al. Antarctic Glacial History Since the Last Glacial Maximum: An Overview of the Record on Land. Antarctic Science. Vol. 10(3). p. 326-344. 1998. 